\title{
The beginnings of communication schools in Spain within their international context
}

\author{
Carlos Barrera
}

Nota: Este artículo se puede leer en español en:

https://revista.profesionaldelainformacion.com/index.php/EPI/article/view/86448

How to cite this article:

Barrera, Carlos (2022). "The beginnings of communication schools in Spain within their international context". Profesional de la información, v. 31, n. 1, e310107.

https://doi.org/10.3145/epi.2022.ene.07

Article received on March $24^{\text {th }} 2021$ Approved on July $5^{\text {th }} 2021$

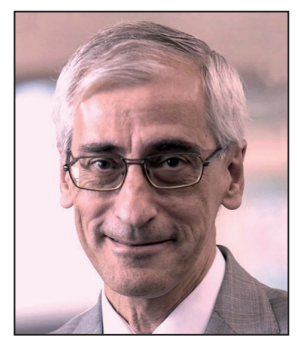

\author{
Carlos Barrera $\square$ \\ https://orcid.org/0000-0001-9771-4074 \\ Universidad de Navarra \\ Facultad de Comunicación \\ Departamento de Comunicación Pública \\ Edificio Ismael Sánchez Bella \\ 31009 Pamplona, Spain \\ cbarrera@unav.es
}

\begin{abstract}
When the first university schools of journalism and communication started in Spain in 1971, only a few European and North American countries had preferentially adopted an academic model. Variety was their dominant feature, exhibiting diverse professional cultures and sometimes political contexts. In countries with a long journalistic tradition such as the UK, learning on the job was the practice at that time. Labor unions were also prevalently responsible for the training of aspiring journalists in France and Germany. In contrast, in the USA, university journalism schools had been established some decades before. In addition, teaching and research in communication evolved via different paths in those countries that had a more noteworthy influence on Spain. The beginning of university-based schools of communication theoretically contributed to the establishment of a more suitable institutional platform for the delivery of communication research trends in the West. An analysis of historical, political, and institutional contexts converging in Spain in the 1970s is useful to describe how the first university schools were shaped in terms of both their incipient teaching and research challenges. A review of the literature covering both fields in Spain and other countries, along with some previously published archival sources, helps us to frame the case of Spain from a transnational viewpoint that considers the impact of contemporary foreign influences. The resulting broader comparative perspective provides a better overarching understanding of the case, even to the point of measuring the extent to which it can be considered a pioneer in this context.

\section{Keywords}

Journalism training; Journalism schools; Schools of communication; Communication research; University; Information sciences; Communication; Journalism; Social sciences; Communication history; Universidad Complutense de Madrid; Universitat Autònoma de Barcelona; Universidad de Navarra.
\end{abstract}

\section{Introduction}

Even though the context in which the first schools of communication developed in Spain had its own distinctive features, the beginnings and initial development of these training and research centers cannot be properly understood without considering the wider framework beyond the more immediate context, in particular the different traditions regarding the teaching of journalism and the trends in communication research existing in the West over the course of the twentieth century, particularly following World War II. 
The new university schools appeared during the final years of Franco's regime, which had closed itself off for a large part of its existence but later opened up to outside influences in many fields, including communication, from the end of the 1950s. The economic and social development of the 1960s, together with the later opening up of public opinion and politics, greatly favored this movement (Terrón-Montero, 1981). The aim of the current study is to describe that outward-looking environment, identify the relations with foreign models, and describe the influences felt when planning the model itself in terms of both teaching and research, which did not always develop at the same pace. Meanwhile, we simultaneously evaluate the extent to which teaching and research in communication existed in Spain and its nature before the creation of such schools in 1971.

We first thus describe in detail the main trends at that time in Western European countries of reference as well as the USA, given that these would provide the major influences on the pioneering schools in Spain. We then consider the main lines along which the first faculties were established and how they developed the beginning of the 1970s. Cross-referencing these two lines of research provides a more accurate overview of the particularities of the Spanish model and, in some respects, its pioneering nature in Europe, despite its supposed delayed incorporation into contemporary research in what was the relatively new scientific field of communication.

The two main components of all academic disciplines, viz. teaching and research, are thus assessed. Under normal circumstances, these should go hand in hand, but in exceptional situations they may appear or develop unequally. In this sense, the creation of schools can, in theory, be seen as one of the factors that had a particularly noteworthy influence on both elements.

A specialized bibliography is applied to carry out this study, in particular books, chapters, and journal articles as well as some primary sources from archives. Works that analyze the actual situation that time are of particular interest because they reveal the tension that arose between different outlooks and often produced contrasting perspectives. Even though some precedents from before the twentieth century do exist, we adopt this as our starting point as its realities are more tangible and specific, marking trends which would take shape over time. We pause to consider the 1970s because our aim is to spotlight the beginnings of schools in Spain rather than their later evolution, except where doing so will shed light retrospectively to enhance their understanding.

We do not aim to use an exhaustive approach in terms of the literature reviewed, as this would result in too much material to be dealt with in a single article. Rather, an attempt is made to gather and order historical elements in both the national and international context, thus aiding an understanding of why and how schools of communication appeared in Spain.

\section{Teaching and research in journalism in Western universities}

World War II marked a turning point for the main European countries as well as other countries influenced by them, in terms of the models of journalism teaching. After the war, and with the emergence of broadcast media, new initiatives were developed with a view to conscientiously train future professionals in this sector. The United Nations, particularly through Unesco, sought to channel such initiatives and expand the concept that specific training programs were required, albeit with uneven results. At the same time, research into journalism also underwent notable changes as a consequence of the war, both in the USA, where communication began to be considered the main object of study, going beyond mere journalism, and in Europe.

\subsection{American schools of journalism and European resistance}

The first two schools of journalism were created in 1908 and 1912, at the universities of Missouri and Columbia (WiIliams, 1929; Boylan, 2003; Weinberg, 2008). These would be followed by others. Around 1940, 542 higher education centers in the USA offered journalism studies to thousands of students (Sutton, 1945). Because of the idiosyncrasies of the US university system, a large fraction of these programs were established in the English and Rhetoric Departments and their quality was not always guaranteed. For this reason, Williams (1925) reduced the number of top-level schools and departments to just 10 or 15.

In any case, several nationwide organizations were soon created, bringing together teachers and schools of journalism. The American Association of Schools and Departments of Journalism unanimously passed a document in December 1924, entitled "Principles and Standards of Education for Journalism," in which it defended the need for

"adequate preparation (...) for all persons who desire to engage in journalism";

training, it added, that

"must be sufficiently broad in scope to familiarize the future journalist with the important fields of knowledge, and sufficiently practical to show the application of the knowledge to the practice of journalism" (Journalism Bulletin, 1925).

From the outset, therefore, a tension between the theoretical or humanistic component and the practical one was present, resulting in the establishment of different types of center depending on their emphasis on one or the other. The lines of research followed by Walter Williams in Missouri and Willard Bleyer in Wisconsin were particularly relevant and 
distinct in their approach (Mirando, 2002; Harnischmacher, 2010). In any case, although there was always criticism of such schools from the professional, or even the academic world, at times being very harsh (Hutchins, 1938), this model managed to become established as the predominant one in that country.

However, this was not the case in the European countries with the greatest tradition in journalism, where the system of learning on the job continued to be the norm. It was only in Germany that the university showed a real interest in journalism, albeit as a subject of study rather than a place where the trade should be learned. German institutes, beginning with that in Leipzig in 1916 and numbering 12 by the 1930s (Barlow, 1936), did not train future journalists but, rather, gave students preparatory intellectual training that had to be complemented with an appropriate professional qualification on the job (Fröhlich; Holtz-Bacha, 2003b). It should be highlighted, in any case, that there was considerable academic interest in journalism research in Germany, which did not occur in other European countries and also did not go unnoticed in certain sectors of US academia. This was the birth of what was called "newspaper science" (Zeitungwissenschaft). Some US authors admired the German contributions as conscientious studies of the press as opposed to the overriding practical nature of the written output of professors from most such schools in the USA (Barrera, 2012).

In England and France, only a few courses at universities in London (1919) and Lille (1924) escaped the general trend, and without much success, despite lasting until World War II. They were accused of not being very practical, so much so that the course in London was described by one of its promoters as "a diploma for journalism" rather than "a diploma in journalism" (Lawson, cit. in Williams, 1922, p. 301). In the 1930s, the general secretary of the French journalists' trade union, Georges Bourdon, publicly expressed his belief that the US model did not have much future (Charon, 2003). In other countries, initiatives for training in the profession of journalism were born in environments outside the university. Indeed, this was the case of Spain's School of Journalism "El Debate," created by the Catholic newspaper of the same name and that existed between 1926 and 1936, with considerable success (Vigil-Vázquez, 1987; Cantavella-Blasco, 2017). As summarized by Stephenson and Mory, the

"development of a combination of vocational training and academic study in one institution did not generally take place" (Stephenson; Mory, 1990, p. 31).

\subsection{Effects of World War II}

At the end of World War II, various aspects of the context in different regions around the world led to changes in how the teaching of journalism was perceived. This had a positive effect on its reputation, thus more thought was given to it by the leaders of many countries. Some of the most noteworthy factors were:

- a greater relevance attributed to the media as public information agencies, as had already been demonstrated during the war;

- the scarcity of skilled professionals as a result of the considerable number of casualties; and

- the appearance or development of powerful media such as radio and television (Desmond, 1949).

In addition, the United Nations promoted meetings, debates, exchange of information, and publications about journalists' education through the Unesco. Some committees of experts made recommendations for the training of journalists through formal teaching and training programs (Casey, 1948; Maheu, 1948).

At times, it seemed that the US model for journalism schools was becoming paradigmatic, recommended, and imitated in other nations, but the political and diplomatic struggle of the "Cold War" around Unesco resulted in gradually declining interest on the part of Americans to win this battle for influence (Blanchard, 1986). In addition, at a basic level, the main European countries continued with the same systems for recruiting and training (more professional than academic) in the 1950s and 1960s, making the USA and Europe two separate worlds (Barrera, 2012), as had already existed before the war. Paradoxically, the countries that most formally followed in the wake of the training of journalists at a university level were communist countries such as the Soviet Union and, under its influence, Poland, Czechoslovakia, and the German Democratic Republic (Barrera; Harnischmacher, 2019), always under strong political doctrinal control.

The British model was defended relentlessly by its promoters, proud of the efficiency that it had shown for centuries. Along those lines, one of its defenders publicly proclaimed:

"These local newspapers are true schools of journalism in which young men and women can imbibe the ideals and methods of a profession which, in Great Britain has been around for 300 years" (Plant, 1967, p. 140).

The system worked because, in the words of another,

"there were always hundreds of young people clamouring to get into journalism," so that "editors could always pick up and choose their new recruits, using as a guide hunch rather than scientific assessment or educational qualifications" (Dodge, 1965, p. 466).

In 1952, the National Council for the Training of Journalists (NCTJ) was created, with the agreement of professional organizations and trade unions, to regulate access to the profession by means of training on the work but based on a more centralized platform. 
In Germany and France, the panorama continued to be practically the same, with strong resistance to allowing universities to take charge of the practical teaching of journalism, although great effort was given to theoretical research. The only school of journalism in Germany, linked to the Süddeutsche Zeitung newspaper, was the Werner Friedmann Institut in Munich, from 1949 (Nixon,

1958). However, this was a preparatory school for joining the profession through the national system called Volontariat. In France, only the school of journalism of the Catholic University of Lille offered courses to would-be journalists. In 1956, it was recognized by professional statutes as a means of accessing the profession. The most relevant teaching institution for media professionals was the Center for the Training of Journalists created in Paris in 1946, with significant input from professional and trade union organizations (Charon, 2003).

There was a greater trans-Atlantic connection and influence in the field of research into mass communication, where following in the wake of the USA, several university research centers were created in the mid-1950s in countries such as the Netherlands, Belgium, France, Italy, and Switzerland (Holmgren, 1968). However, these centers had little in common with the teaching of journalism that was still following the traditional path of learning on the job. In 1943, Wilbur Schramm founded the first department of mass communication in lowa, following his work in a governmental propaganda agency in Washington. This initiative was joined by several other universities in the Midwest, albeit generally at a postgraduate level (Folkerts, 2014). This marked the start of a great controversy in the USA between educators who favored research, called "communicologists" or chi-squares, and those who focused more on teaching the practice of journalism expressively referred to as green-eyeshades (Dickson, 2000). For some news publishers and editors of the time,

"the idea of journalism professors with PhD degrees in social science seemed a foolish, possibly dangerous, trend" (Chaffee; Rogers, 1997, p. 138).

By the 1950s and 1960s, there was an increasing trend in US journalism schools toward establishing their own doctorate programs. This evolution was identified and synthesized in 1960 by Peterson, who pointed out how such schools were going from basically teaching the tricks of the journalistic trade to giving their students a general education that placed the media in a historical, cultural, social, and economic context, replacing the older professionals with

"serious scholars dedicated to a searching study of the mass media as an important social institution worthy of their concern" (Peterson, 1960, p. 580).

Therefore, they had become

"centers of research, and in doing so they have looked to other fields of study for help in discovering what they can about the whole mysterious process of human communication" (Peterson, 1960, p. 580).

As stated by Dennis, to differing extents, schools of journalism began to become

"complex centers for a wide range of professional media training" (Dennis, 1988, p. 14).

The panorama was highly varied and, even though not all schools and departments were moving in the same direction, in general they were moving away from the old stereotype from the turn of the century. Between 1948 and 1970 , in other words in two decades, the number of centers specializing in mass communication increased from 73 to 162 (De-Moragas, 1981).

\subsection{A breath of fresh air, starting in the 1960s}

In Western Europe, the models of teaching journalism that focused more on the vocational and practical aspects, in general, tended to dominate. There was a strong emphasis on learning how to edit or on mixed models that combined teaching at regulated centers, either university or professional, with learning in the workplace. The British, French, and German models, to name the most significant ones, enjoyed long and fruitful years of valuable experience and were thus reluctant to leave the training of professionals in the hands of academia.

Having said that, by the mid-1960s, the first glimmers of disagreement regarding those models became apparent in those countries. Employers and trade unions started to see themselves incapable of taking on the tasks of training young candidates. Léauté (1967), head of the International Center for Advanced Journalism Studies, with its headquarters in Strasbourg and from 1956 under the auspices of Unesco, demonstrated that some countries were following a system midway between academic and professional training. Rod Holmgren perceived

"a mood of experimentation, a desire to try out new approaches, and incidentally an interest in exploring the possibility of adapting the American system to Europe's needs and institutions" (Holmgren, 1968, pp. 9-12).

In fact, in the 1960s and the start of the following decade, almost the whole of Western Europe witnessed a first wave, although somewhat limited, of creation of new journalism programs being set up at universities: firstly, in the French universities of Bordeaux (1967) and Tours (1968), as well as in Cologne (1968) and Cardiff (1970). Germany followed with the Universities of Munich (1973), Dortmund, and Hohenheim (1976), and in England at London City University (1976). 
Starting in 1962, a journalism course was also on offer at Lancashire Polytechnic. In any event, these were not schools in the true sense of the word but rather preparatory programs before entering the workplace learning system and/or departments where research was also carried out at the same time. Overall, they were exceptions to a system based on nonacademic, but vocational, teaching. In fact, as stated by Esser in the case of the UK,

"neither media employers nor media trade unions responded with much enthusiasm" (Esser, 2003, p. 225)

to these initiatives, although they did manage to consolidate themselves and achieve legal recognition as alternative routes into the profession.

It was not until the 1990s that a second wave changed the panorama in many European countries in a sense of becoming "academic" (Barrera; Harnischmacher, 2019), but that period lies beyond the scope of this study, which focuses on the initial context. However, it does serve as a reference time for some trends that began beforehand and became consolidated, gaining ground on the more "professionalized" teaching of journalism and communication. For this reason, when speaking about Spain for comparison, Alfonso Nieto did not hesitate to state that,

"in the history of European universities, our country was the first to wholly incorporate the teaching of Communication and Information into the University" (Nieto, 2008, p. 74).

\section{The first schools of communication in Spain and their context}

\subsection{Difficulties in their creation}

In September 1971, a decree approved the creation of two schools of communication, at the Universidad Complutense de Madrid and the Universitat Autònoma de Barcelona. In April 1972, a new decree approved a change in the name of the Institute of Journalism of the Universidad de Navarra, which had been operating since 1958, to the School of Communication. The academic pathway for the first three universities for the training of journalists and other communication professionals was thereby opened (Sánchez-García, 2017; García-Nieto; Davara-Rodríguez, 2020).

The law that made this possible had, somewhat surprisingly, been included through a transitional provision in the new General Education Law, approved in July 1970. The least glamorous and most pragmatic route, and one that would cause the least political debate, was chosen deliberately, in the interests of making this more feasible. Among the representatives of the Francoist parliament, there was not much support for the idea, and the plan of its main promoters was to move it forward as discretely as possible with the aim of eventually getting it passed (Vigil-Vázquez, 1987; Nieto, 2008).

A little over a year separated the General Education Law (passed on 4 August 1970) and the actual creation of the faculties. This period was not without its uncertainties, largely due to the disdain previously shown by the Spanish university system that suddenly became interested in adopting a position on what would be the new schools of communication. For these to start, university professors would be needed, unlike what happened in the case of the Official Schools of Journalism (1941), Cinema (1962), Advertising (1964), and Radio and Television (1967), all of which still had, basically, a professional nature (García-Nieto; Davara-Rodríguez, 2020). These would all gradually disappear with the arrival of the faculties, with the exception of the latter, which became the Official Institute of Radio and Television under Radio Televisión Española (Jones, 1997).

The government's delay in regulating the new academic degrees was indicative of the presence of resistance and internal wranglings. Finally, between August and October 1971, the foundations were laid. The regulatory decree of "Journalism and media studies at university" arrived on 13 August. To help the transition, an Inter-Ministerial Board was set up, made up of members of the teams of the departments involved: Information and Tourism, which surrendered control of those studies, and Education, which incorporated them into its academic structure (Nieto, 2008; García-Nieto; Davara-Rodríguez, 2020). The Universidad Complutense de Madrid and Universitat Autònoma de Barcelona urgently requested the creation of their corresponding schools of communication, which were established by decree on 17 September.

Since those decrees were passed at the beginning of the academic year, it was not easy to organize the start of classes for the students enrolled. At the Universitat Autònoma de Barcelona, the first two years were taught in provisional premises in Egipcíaques Street (Recoder-Sellarés, 2020). At the Universidad Complutense de Madrid, the classes did not start until February 1972, in an extension to the facilities of the Official School of Cinema, with over 700 students enrolled (García-Nieto; Davara-Rodríguez, 2020). In Pamplona, based on the continuity from the previous Institute of Journalism, there were no such logistical and material problems. The ministerial go-ahead for the school of communication at the Universidad de Navarra would arrive in April 1972. Internally, its transformation into a faculty had taken place during the autumn, awaiting the definitive green light from the administration (Barrera, 2009).

Those tortuous initial steps were a result of both the lack of a syllabus for the new degree courses and the difficulties mentioned above, which were inherent to the contracting of appropriate teaching staff. There was also a need to overcome the reluctance that remained in certain professional sectors regarding the academic nature of communication studies. In fact, the outline of the syllabus was the number one priority of the main academic authorities in the three new schools. They counted upon, firstly, the experience gained from regulated (albeit nonuniversity) courses from the official schools that were being removed, and also from the Institute of Journalism of Navarre within an academic environment. Jones points out how the main teething problems for the schools, in particular the public ones, was 
"the excessive number of students, the sub-standard teaching of professors, insufficient technical equipment for the academic and professional training of students and the unsuitability of the syllabus to social and professional demands" (Jones, 1997, pp. 107-108).

These were not simple issues that could be resolved in the short term.

\subsection{Types and traditions in the teaching of journalism}

When it came to the teaching of journalism, Spain was not a case isolated from the rest of Europe or the West as a whole. Some comparative international studies (understandably) placed it among the countries with an academic tradition, albeit more recently when compared with the USA (Fröhlich; Holtz-Bacha, 2003a). This group also included Finland and Canada, although with their own specific characteristics and contexts. It is true that, in 1971, Spain did not boast such a tradition because journalism training really took place based on a mixed model that combined professional teaching and learning on the job. The professional schools were mostly controlled by the state, although before Franco's regime, there had been one important private school, that of El Debate (1926-1936) (Cantavella-Blasco, 2017) and, in 1958, one appeared within the Universidad de Navarra, viz. the aforementioned Institute of Journalism (Barrera, 2009). Learning at the workplace itself was also commonplace, following the purest British, French, or German style, but without the control of the employers' organizations or trade unions that are typical of those countries.

The creation of schools of communication between 1971 and 1972 placed Spain, at least formally, within the tradition that linked the teaching of journalism and other media to the university, the most famous and obvious example being the US journalism schools. The fact that, over the years, most people who began careers in journalism and other communication professions came from university schools (Navas; Sánchez, 1995) indicated the growing establishment of this model and its formal assimilation into US schools. Both before and after 1971, when faculties were taking their first steps, the study of another degree in addition to journalism was not uncommon

The creation of schools of communication between 1971 and 1972 placed Spain within the tradition that linked the teaching of journalism and other media to the university, the most famous and obvious example being the US journalism schools (García de Cortázar; García-de-León, 2000).

It is revealing that one of the promoters of the operation in Spain, Alfonso Nieto, in a letter to Emilio Romero on the 18 May 1971, when the government's regulatory decree was still eagerly awaited, told him (after a long stay in the USA) that

"I was delighted to observe that the orientation which has been given to the teaching of journalism in Spain coincides completely with that of the best schools in the USA" (cit. in Barrera, 2009, pp. 167-168).

Nieto was, at that time, the director of the Institute of Journalism of Navarra, and Romero held the same position at the Official School of Journalism. Both had thrown themselves totally, mobilizing their contacts, behind the political operation to raise those studies to the higher education level.

\subsection{Universities as institutional platforms for research in journalism and communication}

The first and most urgent task of the new schools created in Spain was to organize the five-year syllabus that would be imparted to students in the three "sections," as they were then known, passed by ministerial decree: journalism, advertising, and sciences of the visual image and audio. The Complutense began the three sections in the first year, the Autònoma began with journalism studies, incorporating advertising in 1972, whereas Navarra only began journalism. In 1975 , the advertising section at the Complutense changed its name to advertising and public relations. In any case, the very mention of this scenario is indicative of the magnitude of the teaching task that had to be tackled, bearing in mind, in addition, the large number of students enrolled in these new schools. There were already 3,733 in the academic year 1972-73 (Navas; Sánchez, 1995), reaching some 10,000 by 1977 (De-Moragas, 1981).

The training of professors to teach journalism, advertising, public relations, and audiovisual communication required time, all the more so if the goal was to rely on PhD students coming from these very schools of communication as a way of consolidating the discipline. Until then, because of these very circumstances, most had to come from other faculties, particularly from the fields of social sciences and humanities. A further contingent was made up of journalists and communication professionals who enrolled as teachers to contribute their own professional expertise (Gifreu, 1988; Gomis et al., 2002).

These relevant circumstances pertaining to the beginnings meant that it was necessary for the new academic authorities of these schools to focus their efforts on training the people required to set them in motion (official state examinations for different categories, preparation of doctoral theses, etc.) as well as providing the necessary material and technical infrastructure (De-Moragas, 1981). In the 1972-73 academic year, there were 139 professors for the three faculties (Salaverría; Barrera, 2009). Despite not being the most urgent aspect, these became the platforms where the emerging research in communication found its most natural setting. 
Previously, this had sometimes been carried out in isolation by authors such as Beneyto (1957) in his work Mass Communications, which spread the US line of research of the same name. Many years later, Ángel Benito would consider it

"the first attempt in the Spanish language to carry out a systematic study of all media" (Benito, 1986, p. 13).

On other occasions, research was channeled through the sole university institution that housed journalism studies, viz. the Institute of Navarra. From 1964 onward, the so-called Cuadernos de Trabajo (Working Notebooks) of that institute published a serial that would be the first organized, methodical collection in the journalism field in Spain. In the words of Daniel Jones,

"this institution boasted a team of researchers which placed it at the forefront of academic activity in Spain at that time and the careful editions of its own works and translations of foreign authors were held in high regard in other centers both in the country and Latin America" (Jones, 1998, p. 20).

By contrast, the Official School of Journalism "had, in its three decades of history, virtually no theoretical output" (Jones, 1989, p. 142), as a result of its different nature.

The establishment of the first three schools led to a definitive channeling of communication research. The first professors of these faculties felt the need to obtain (if they had not already) a PhD in order to continue their academic career. Of the first graduates, some went on to obtain their doctorate at schools in the fields of social sciences and humanities, given that there were not yet any PhD programs in communication studies. Others waited until these were launched, even though that meant a considerable wait because they had first to complete their 5-year undergraduate degree. The first doctor in communication in Spain was Ángel Faus, who read his thesis, entitled "Technology in television news production," on 10 March 1979 at the Universidad de Navarra. Two years earlier, the Ministry of Education had approved the PhD program submitted by the academic authorities of Navarra (Barrera, 2009). Logically, the topics of the first theses at Spanish universities were often along the lines of the research of doctoral professors.

\subsection{Favorable circumstances}

Some historical, political, and socioeconomic circumstances undoubtedly contributed to this breakthrough. The end of Franco's dictatorship brought about a certain social and political opening in the final years of his regime, together with the development and modernization of the country. This contributed to the gradual standardization of Spain and other surrounding nations and the arrival of ideas and intellectual approaches that, until a short time before, had been semiclandestine. At the same time, liberalization of public opinion through the new Press and Printing Law in 1966, although partial and limited to newspapers and magazines, was an opportunity for a definitive depoliticization of the means of access to the profession of journalism that, invariably, meant the removal of the Official School of Journalism, itself dependent upon the Ministry of Information and Tourism (Martínez-Nicolás, 2008). This had been created in 1941 as an instrument to exercise political control over access to journalism, underwent a series of phases throughout two decades, and, at one point, had offices in Madrid and Barcelona (De-Aguinaga, 1980; Vigil-Vázquez, 1987).

The economic, social, and technological development in Spain through the 1960s, along with the new opening policy measures in the area of journalism, revived the print media sector, which had become stagnated and almost bereft of dynamism (Chuliá, 2001). The competition, both commercial and ideological, became all the more apparent in the two large markets of Madrid and Barcelona (Alférez, 1986; Guillamet, 1996) and, naturally, had a positive impact on the advertising industry (Montero-Díaz et al., 2010). The transformation of television into the mass medium par excellence, gradually reaching most households, was another factor that boosted advertising (Palacio, 2001).

From a professional point of view, the call for an increasingly demanding level of training for those aiming for a career in journalism became apparent, despite internal debates questioning this need. In 1968, a journalist from the evening newspaper Pueblo, José Bugeda, claimed unreservedly:

"Journalism is not a subject for academic study (...) No matter how we look at it, a School of Journalism will always be a school for professional training" (Bugeda, 1968, p. 2).

This was his reply to the opposite point of view that had been set out by Luis María Anson in an article in the morning newspaper $A B C$, entitled "Faculty of Journalism," in defense of

"more responsible, better trained and better skilled journalists" (Anson, 1968, p. 41).

This process ran alongside an increase in the number of young people enrolled at Spanish universities in the 1960 s. In the specific case of those beginning a career in journalism, there was also a growing number of journalists who were joining editorial offices with a university degree, in other words, who had more intellectual baggage than was the norm at that time (García-de-Cortázar; García-de-León, 2000). Quite often, they would combine a university degree with their studies at the Official School (at its two headquarters in Madrid and Barcelona), the Navarra Institute of Journalism, or the Church's School of Journalism, which came into existence in Madrid in 1960 and Barcelona in 1964. 
It was a fact that the younger generations took a greater interest in journalism from the 1960s onward. Economic development and a certain political opening made it more appealing for them. As part of a generation that had not witnessed the Spanish Civil War, their links to the dictatorship were, in general, either weaker or directly against it. In Barcelona, the Grup Democràtic de Periodistes was organized as an underground pressure platform operating in favor of democracy (Roglan, 1992); many of their meetings were held under the shelter of the Barcelona section of the Church's Journalism School (De-Moragas, 1981). The magazine Gaceta Universitaria (1964-1972), which would suffer many fines, penalties, and closures, was born within the Pamplona Journalism Institute, although it would soon move to Madrid (Barrera, 2001).

At the same time, journalism schools and institutes in the 1960s were gradually becoming more aware of the need to raise the standard of teaching and the social and professional recognition of their studies, in an attempt to approach the academic model of university-based schools. In that sense, in 1967, there was a reform of the syllabus, passed by the Ministry of Information upon which it depended. It became a four-instead of three-year program, so that the schools would be considered centers of higher education, in other words, the equivalent of university-level degrees, albeit without being formally recognized as such.

Although there was a clear trend toward raising teaching standards, not all the sectors involved agreed on this point. The Head of the Official School, Bartolomé Mostaza, could not think of any specific university faculty

"ready to take on, at the same time and of immediate effect, the type of studies and techniques which should be covered in a journalism degree" (Mostaza, 1966, p. 31).

In contrast, Benito reminded the minister Fraga in a letter dated 21 January 1966 that,

"in Pamplona, we sought from the beginning a higher level center, conceived in the style of a Faculty and with a single qualification, albeit with a diversity of professional specializations" (cit. in Barrera, 2001, p. 1347).

Benito, writing a short time later, was aligned with the trend observed in universities in the USA, South America, Asia, and France:

"a Higher School for training in the different mass media, which would be fully integrated, both by its quality standards and syllabus, in the framework of the University -or outside but always with a higher level-closely linked to newspaper companies and served by university professors and news professionals" (Benito, 1967, p. 25).

In other areas of communication too, such as public relations, there was a notable interest in integrating them within a specific academic program, running parallel to their emerging professionalization. Several proposals along those lines emerged from the First Spanish Congress on Public Relations in May 1966 (García-Nieto; Davara-Rodríguez, 2020), and shortly afterwards, in 1968, the Higher School of Public Relations was created, dependent upon the Universitat de Barcelona (Castillo; Xifra, 2006).

\section{The shaping of a scientific tradition in Spain}

\subsection{University schools as an institutional framework}

According to several authors, the creation of the schools of communication in the academic year 1971-1972 was the basic milestone that enabled the start of communication research in Spain with a more solid foundation, always observing the external examples of trends and schools of thought from neighboring countries (De-Moragas, 1981; Jones, 1998; García-Jiménez, 2007; Martínez-Nicolás, 2008; López-Escobar; Martín-Algarra, 2017). They turned into

"a more appropriate institutional framework (...) for the emergence of a scientific community" (Martínez-Nicolás, 2008, p. 20).

A certain consensus was thus reached that, rather than a need for communication professions to be simply taught, the goal should be to make them the subject of scientific research. At this point, the university seemed to be the institution that, logically, should be responsible for making this a reality (Nieto, 2008). It was at the faculties where the "expansion and professionalization" of research into contemporary communication phenomena took place (Jones, 1997, pp. 112113).

Hitherto, in a planned sense (as far as the experience of the university sphere was concerned) it was only possible to talk about what had been done in Navarra. For 13 years, seminars, week-long studies, and congresses, for example, the International Association for Mass Communication Research (IAMCR) conference in 1968 (Barrera, 2019), were held there, as well as a selection of other activities spanning the professional and academic, in tune with the principles that led to its creation. As De-Moragas wrote,

"in the barren research panorama of those years, the texts and methodological influences of the University of Navarra provided the journalism schools with their main academic and theoretical resources" (De-Moragas, 1981, p. 228).

Other activities, ranging from professional and academic, were carried out in the context of official schools or the summer courses in the Universidad International Menéndez Pelayo. 
From the important perspective of personal relations, from the late-1950s onward, there had been increasing interaction between Spanish professionals, experts, and professors, at both official and private centers, and their colleagues in international events and organizations, such as Unesco, IAMCR, and the Strasbourg International Conversations (De-Moragas, 1981). These contacts led to the end of Spain's isolation on the international scene, and direct contact with the main problems that they tackled, using a transnational approach (De-Aguilera, 1998).
The very dynamic of how the first academic staff of the faculties was put together, with professors from diverse backgrounds, led to a highly multidisciplinary nature when it came to dealing with communication and the media as a subject for scientific study

The name that was first given to these schools in Spanish was not "of communication" but "of information sciences", in line with the traditions of Southern European countries such as France and Italy, where the term "information" was attributed almost indistinctly to the general phenomenon of the media, without taking into account the meaning of the term in English, which was applied more to the area of IT and computers. In the English-speaking world, information science has been and still is an academic discipline linked to documentation and libraries. Over time, the term "information" would gradually disappear as an official name for Spanish schools, to the point of becoming a minor one. In general, it became replaced by the internationally more accepted terms "communication," "communication science," or similar. Aiming to provide clarity, since the beginning we have used the term "schools of communication" to refer to them.

The background of the professors at the new schools was diverse (Martínez-Nicolás, 2007; López-Escobar; Martín-Algarra, 2017). Some, in Madrid and Barcelona, came from the old official schools or that run by the church, and they taught subjects in a more technical or practical way. Others transferred from the teaching staff of other existing faculties (philology, law, history, political science, etc.) with some overlap in their syllabi; they saw in the new school opportunities for advancing their academic careers. There were also professionals from the world of journalism and communication who, with their corresponding university degree, took the step from the profession to academia, beginning their doctorates in communication-related topics in other faculties; the first theses about public relations, for example, were read at the School of Economics of the Universidad Complutense (Castillo; Xifra, 2006). At Navarra, the staff was made up with a university style, albeit accepting the presence of professionals, so that the transformation of the institute into a school was smoother (Barrera, 2009).

This variety of backgrounds, brought about by the sudden approval of the schools and the lack of time to supply them with the necessary human and material resources, goes some way toward explaining the

"lack of coherence in the concept of communication they [the first professors and researchers] worked with" (López-Escobar; Martín-Algarra, 2017, p. 88).

However, the bringing together of them all in specific schools went a long way to laying the intellectual and theoretical foundations upon which the area could be built in Spain, usually taking their lead from the main trends existing in the Western world as inspiration.

\subsection{How the different research traditions were received}

The Universidad de Navarra's Institute of Journalism was established in 1958 with a strong humanistic influence, which was typical of the academic scenario that gave it shape. From the outset, it was a center with a research vocation. This is how it was expressed in 1968 by the president of the university, Francisco Ponz, at the IAMCR conference, when he stated that the academic integration of communication studies had been carried out because

"it was necessary to greatly favour the corresponding teaching and research" (IAMCR, 1970).

The first director was Antonio Fontán, a professor of Latin and also a journalist (Cosgaya-García, 2020). As he himself and his first main fellow-workers have expressed, he was inspired by the Central European universities that he had visited in the Netherlands, France, and especially, Germany (Gomis et al., 2002; Benito, 2003). He was in contact with the German tradition of "newspaper science" or Zeitungwissenschaft, which later became Publizistik, and other approaches, such as those of the French Kayser for analyzing newspapers. He studied in depth the theories of the press as offered by German universities, with "a conception of journalism as a technical fact and a social fact" (Benito, 2003, p. 87), introducing Emil Dovifat even before his work was translated into Spanish in Mexico (Dovifat, 1959).

With him and his successor as director, Ángel Benito, the ideas of the Italian Fattorello regarding information were also gathered and published (De-Moragas, 1981; Barrera, 2009). Through the professor Ángel Faus, whose training also had German roots, Otto Groth's work also spread from Navarra (Faus-Belau, 1966). On the other hand, Martínez Albertos familiarized himself more with the US approaches to newspaper editing, a field in which he would soon become a reference figure (Gomis et al., 2002). In any case, it was the German tradition, as described by Martínez-Nicolás (2008), that to a greater extent established the me-

The faculties grew institutionally into appropriate platforms from which it was possible to begin producing research that would gradually reach the level observed in developed countries 
dia as a subject of scientific study in Navarra. Much later and to a certain extent, this would be reconsidered and renewed by authors such as Casasús and the so-called "Periodística" (Casasús, 1991; López-Pan, 2010).

In 1963, the first volume of the so-called Institute of Journalism's Working Notebooks was published. This collection would gather, in the 1960s, the first systematic set of research work carried out at the center. In its prologue, the director Ángel Benito spoke of the need for a

"a wise mix - which is also a creative tension - of research and free study of all disciplines and the teaching of the most diverse bodies of doctrine" (Benito, 1963, p. 13).

He also referred to the

"public expression of that research work -primary and elementary, if you like- but spurred on by the interest in being the first studies on journalism that are being undertaken in Spain through proper plan and following scientific methods" (Benito, 1963, p. 13).

In a different cultural context, but equally influential regarding its reception in Spain, the tradition of research into mass communications, as developed by authors such as Lasswell and Lazarsfeld in the USA, appeared. The decade of the 1960s, and especially its second half, also witnessed the introduction of works on communication and mass culture by leading foreign authors, thanks to the Spanish translations of their works (Morin, 1966; Adorno, 1966, McLuhan, 1969). By this means, even beyond the faculties themselves, the approach of the Frankfurt School and semiotics arrived (De-Moragas, 1981; Martínez-Nicolás, 2008). The most direct influence was notable with the creation of the schools of communication the following decade.

The organization of congresses, day courses, symposia, and conferences in the new schools was a catalyst for the, now institutional, beginning of research with

"the conviction that the media demand a complex theoretical treatment" (De-Moragas, 1981, p. 238)

going beyond mere presentation by professionals who are not dedicated to academic research tasks. The very dynamic of how the first academic staff of the faculties was put together, with professors from diverse backgrounds, led to a highly multidisciplinary nature when it came to dealing with communication and the media as a subject for scientific study (Gifreu, 1988).

These research traditions were received in Spain somewhat later because they could not enter earlier due to the closed nature of Franco's regime. However, they did serve to lay the foundations for the first schools and for training their lecturers and researchers in a distinctive, scientific task, albeit with a connection to the rest of the social sciences to which communication aspired to join. To achieve this, it was necessary to develop its own identity and methods,

"to establish an autonomous epistemological space for communication research" (Martínez-Nicolás, 2008, p. 25).

The go-ahead for the schools of communication required those efforts in an attempt to place the new discipline at the same academic level as those that enjoyed a longer tradition. In this way, a

"certain critical mass of researchers and the standardization of our scientific output with that which was developed in other countries"

would be formed (De-Aguilera, 1998, p. 8).

As noted by Berrio (1997), one distinctive aspect of research into communication in Spain, setting it aside from most advanced countries, is that it was developed

"within -or related to- journalism and not within sociology or political science (...) as would seem more appropriate based on strictly scientific criteria" (Berrio, 1997, pp. 23-24).

These two disciplines of social science, which were the object of restrictions by Franco's regime, had prospered in fully democratic states and influenced the progress of the youngest discipline of communication, in stark contrast to what happened in Spain. With the end of the dictatorship, these two academic fields could take shape without the prior political hurdles (Gifreu, 1988).

\section{Conclusions}

Through the establishment and setting in motion of the schools of communication in the academic year 19711972, Spain became an academic outpost in Western countries by establishing university degrees as the common way to access the professions of journalism and other communication-related jobs in advertising, public relations, and audiovisual communication. In this way, these studies formally reached the same level as the rest of the social sciences and, in general, all disciplines from the academic world.
Through the establishment and setting in motion of the schools of communication in the academic year 1971-1972, Spain became an academic outpost in Western countries by establishing university degrees as the common way to access the professions of journalism and other communication-related jobs 
From a comparative perspective, it may be surprising that Spain placed itself at the cutting edge, in Europe, of the academic models of journalism when compared with the most common practices in neighboring countries, which focused their professional training on the workplace. In the 1960s, reliance on the academic model was not very widespread either in Spain or in many countries. There were serious misgivings both within the profession and academia, hence this process in Spain was carried out quickly and subtly, albeit with the knowledge and consent of the ministries involved: Education and Information and Tourism. The heads of the Official School of Journalism and the Navarre Institute of Journalism were in favor, giving their full supporting to this approach. It may also be surprising that this was carried out during a dictatorship. Admittedly, other, communist countries had already adopted this model years before, albeit with strong ideological control.

Despite these advances in the academic model for the teaching of journalism, Spain suffered a notable historical backwardness compared with the main traditions of research into journalism and communication, which was the other necessary component for the model to become fully consolidated. Until 1971, only the output of one-off authors, the work of the Institute of Journalism within the Universidad de Navarre, and the still unsystematic arrival of prestigious foreign authors made up the basic panorama of research in Spain. German newspaper science and US research into mass communication, along with other low-key specific contributions, were the main trends among emerging researchers. These traditions served to lay the bases, even though they were being questioned and, sometimes, displaced, by new critical intellectual approaches in European and US universities. Their ability to gain a footing in Spain was helped by the establishment of schools and the primary need to teach students the models of the day.

The pressing need to provide the new students at these schools with the necessary university training meant that, at the beginning, a considerable amount of effort was devoted to teaching rather than research. However, the faculties grew institutionally into appropriate platforms from which it was possible to begin producing research that would gradually reach the level observed in developed countries. Obviously, this process would take years. In any case, Spain was never oblivious to the winds blowing from neighboring academic contexts, in other words, the Western world to which it belonged.

Institutionally, it had already been doing so since the 1950s through its presence in the most prestigious international forums where the teaching of journalism was discussed, particularly under the auspices of Unesco. The impact of the US schools of journalism, which was already evident in their day when the first school was created by El Debate, continued to be fundamental to the configuration of the first schools, particularly regarding their syllabi. The different schools of research existing in Western Europe, both the more traditional approach and the new and critical ones emerging later, also had a considerable influence.

From a chronological comparative viewpoint, Spain thus appears as a pioneer in the academic integration of journalism given that, in 1971, virtually no other country in Western Europe had university degrees leading to a qualification to work in journalism or other communication professions. The liberalization of the academic path of the teaching of journalism was a means of escaping a sociopolitical and communicative reality that was unsustainable, similar to Franco's regime itself, which was crumbling under the contradictions caused by the impossibility of its modernization. The schools of communication were not a natural result of the evolution of official schools, particularly that of Journalism, given that there was a clear rupture from what they were and meant, including their internal organization and purposes. In fact, they disappeared immediately, even though they did fulfil (at least in part) their function in tending towards the professionalization of journalism. The latter did not occur so clearly in the rest of the official schools, where the studies were of a more technical nature.

Research, as a binding element of any university center, basically trailed behind and was inspired by external sources, as mentioned above. The creation of institutionalized schools such as those of Madrid, Barcelona, and Navarra was the backing that provided them with a more solid and visible infrastructure in the academic and research sectors in Spain and, over time, at an international level. Another feature that favored their gradual development and later international standardization was the arrival of democracy from 1975 onward. That being said, note that this creation occurred in the latter days of Franco's regime and without full consensus from the professional and academic spheres.
The schools of communication were not a natural result of the evolution of official schools, particularly that of Journalism, given that there was a clear rupture from what they were and meant, including their internal organization and purposes 


\section{References}

Adorno, Theodor W. (1966). Televisión y cultura de masas. Córdoba, Argentina: Eudecor.

Alférez, Antonio (1986). Cuarto poder en España: la prensa desde la ley Fraga 1966. Barcelona: Plaza \& Janés. ISBN: 978 8401333217

Anson, Luis-María (1968). "Facultad de Periodismo". ABC, 19 junio, p. 41.

Barlow, Reuel R. (1936). French and British schools of journalism with a comparative analysis. Journalism quarterly, v. 13, n. 2, pp. 157-168. https://doi.org/10.1177/107769903601300203

Barrera, Carlos (2001). "Una idea universitaria de la comunicación en los años 50 y 60: el Instituto de Periodismo de Navarra". En: Ripoll-Molines, Fernando (ed.). Las mil caras de la comunicación: homenaje al Profesor Don Ángel Benito. Madrid: Servicio de Publicaciones, Facultad de Ciencias de la Información, Universidad Complutense, v. 2, pp. 13331367. ISBN: 9788492227594

Barrera, Carlos (2009). Historia de la Facultad de Comunicación de la Universidad de Navarra. Medio siglo de enseñanza e investigación. Pamplona: Eunsa. ISBN: 9788431326357

Barrera, Carlos (2012). "Transatlantic views on journalism education before and after World War II: two separate worlds?". Journalism studies, v. 13, n. 4, pp. 543-549.

https://doi.org/10.1080/1461670X.2011.637722

Barrera, Carlos (2019). "Cold war, press freedom and journalism education: paradoxes of the untypical 1968 IAMCR conference in Pamplona". Javnost-The public, v. 26, n. 4.

https://doi.org/10.1080/13183222.2019.1633608

Barrera, Carlos; Harnischmacher, Michael (2019). "The development of journalism education in Europe”. In: Arnold, Klaus; Preston, Paschal; Kinnebrock, Susanne (eds.). The handbook of European Communication history. Hoboken, NJ, USA: Wiley Blackwell, pp. 367-384. ISBN: 9781119161622

Beneyto, Juan (1957). Mass communications: un panorama de los medios de información en la sociedad moderna. Madrid: Instituto de Estudios Políticos.

Benito, Ángel (1963). “Presentación”. En: De-Villanueva, Juan-Pablo. La dinámica y el valor de la opinión pública. Pamplona: Cuadernos de Trabajo del Instituto de Periodismo de la Universidad de Navarra.

Benito, Ángel (1967). “Evolución de los estudios de periodismo en el mundo”. En: Benito, Ángel. Ciencia y enseñanza del periodismo. Pamplona: Eunsa. ISBN: 9788431300012

Benito, Ángel (1986). “Introducción”. En: Equiza, Pilar. Juan Beneyto: periodismo y universidad. Alicante: Caja de Ahorros Provincial de Alicante. ISBN: 9788486314330

Benito, Ángel (2003). "Puso al periodismo en su sitio". Nueva revista de política, cultura y arte, n. 89, pp. 85-91. https://www.nuevarevista.net/destacados/puso-al-periodismo-en-su-sitio

Berrio, Jordi (dir.) (1997). Un segle de recerca sobre la comunicació a Catalunya. Barcelona: Universitat Autònoma de Barcelona. ISBN: 9788449007880

Blanchard, Margaret A. (1986). Exporting the first amendment: the press-government crusade of 1945-1952. New York: Longman. ISBN: 9780582284302

Boylan, James R. (2003). Pulitzer's school. Columbia University's School of Journalism, 1903-2003. New York: Columbia University Press. ISBN: 0231130902

Bugeda, José (1968). “Periodismo y Universidad”. Pueblo, 27 junio, p. 2.

Cantavella-Blasco, Juan (2017). La Escuela de Periodismo de "El Debate": primeros pasos para la formación de periodistas en España. Madrid: CEU. ISBN: 9788416477685

Casasús, Josep M. (1991). “Evolución de los estudios de Periodística”. En: Casasús, Josep M.; Núñez-Ladevéze, Luis. Estilo y géneros periodísticos, pp. 37-59. Barcelona: Ariel. ISBN: 9788434412583

Casey, Ralph D. (1948). “Unesco's role in advancing education for journalism”. Journalism quarterly, v. 25, n. 4, pp. 386-390. https://doi.org/10.1177/107769904802500411

Castillo, Antonio; Xifra, Jordi (2006). “Investigación bibliométrica de las tesis doctorales españolas sobre relaciones públicas (1965-2005)". Análisi: quaderns de comunicació i cultura, v. 34, pp. 141-161.

https://www.raco.cat/index.php/Analisi/article/view/55449 
Chaffee, Steven H.; Rogers, Everett M. (eds.) (1997). The beginnings of communication study in America: a personal memoir (by Schramm, Wilbur). Thousand Oaks, CA, USA: Sage. ISBN: 0761907157

Charon, Jean-Marie (2003). “Journalist training in France”. In: Fröhlich, Romy; Holtz-Bacha, Christina (eds.) (2003). Journalism education in Europe and North America: an international comparison. Cresskill, NJ, USA: Hampton Press, pp. 139-167. ISBN: 1572733810

Chuliá, Elisa (2001). El poder y la palabra. Prensa y poder político en las dictaduras: el régimen de Franco ante la prensa y el periodismo. Madrid: Biblioteca Nueva/UNED. ISBN: 9788470309137

Cosgaya-García, Jaime (2020). Antonio Fontán (1923-2010): una biografía política. Pamplona: Eunsa. ISBN: 9788431334949

De-Aguilera, Miguel (1998). "La investigación sobre comunicación en España: una visión panorámica”. Comunicación y cultura, v. 2, n. 4, pp. 5-11.

https://dialnet.unirioja.es/servlet/articulo?codigo=2901273

De-Aguinaga, Enrique (1980). Periodismo, profesión: estudio para la definición objetiva del ejercicio profesional del periodismo. Madrid: Fragua. ISBN: 9788470740480

De-Moragas, Miquel (1981). Teorías de la comunicación: investigaciones sobre medios en América y Europa. Barcelona: Gustavo Gili. ISBN: 9788425210785

Dennis, Everette E. (1988). "Whatever happened to Marse Robert's dream? The dilemma of American journalism education". Gannet center journal, v. 2, pp. 2-22.

Desmond, Robert W. (1949). Professional training of journalists. Paris: Unesco.

Dickson, Tom (2000). Mass media education in transition: preparing for the $21^{\text {st }}$ century. Mahwah, NJ. USA: Lawrence Erlbaum Associates. ISBN: 0805830979

Dodge, John (1965). "Britain re-jigs its training scheme". Journalism quarterly, v. 42, n. 3, pp. 466-470. https://doi.org/10.1177/107769906504200317

Dovifat, Emil (1959). Periodismo. Ciudad de México: Unión Tipográfica Editorial Hispano Americana.

Esser, Frank (2003). "Journalism training in Great Britain: a system rich in tradition but currently in transition". In: Fröhlich, Romy; Holtz-Bacha, Christina (eds.) (2003). Journalism education in Europe and North America: an international comparison. Cresskill, NJ, USA: Hampton Press, pp. 209-236. ISBN: 1572733810

Faus-Belau, Ángel (1966). La ciencia periodística de Otto Groth. Pamplona: Universidad de Navarra, Instituto de Periodismo. ISBN: 9788431300036

Folkerts, Jean (2014). "History of journalism education”. Journalism \& communication monographs, v. 16, n. 4, pp. $227-299$. https://doi.org/10.1177/1522637914541379

Fröhlich, Romy; Holtz-Bacha, Christina (eds.) (2003a). Journalism education in Europe and North America: an international comparison. Cresskill, NJ, USA: Hampton Press. ISBN: 1572733810

Fröhlich, Romy; Holtz-Bacha, Christina (2003b). "Journalism education in Germany: a wide range of different ways". In: Fröhlich, Romy; Holtz-Bacha, Christina (eds.). Journalism education in Europe and North America: an international comparison. Cresskill, NJ, USA: Hampton Press, pp. 187-205. ISBN: 1572733810

García-de-Cortázar, Marisa; García-de-León, María-Antonia (2000). Profesionales del periodismo: hombres y mujeres en los medios de comunicación. Madrid: CIS/Siglo XXI. ISBN: 9788474763102

García-Jiménez, Leonarda (2007). Las teorías de la comunicación en España: un mapa sobre el territorio de nuestra investigación (1980-2006). Madrid: Tecnos. ISBN: 9788430946549

García-Nieto, María-Teresa; Davara-Rodríguez, Francisco-Javier (2020). “La génesis de las facultades españolas de Ciencias de la Información: del periodismo y de las relaciones públicas”. Aportes, v. 35. n. 103, pp. 35-68.

http://revistaaportes.com/index.php/aportes/article/view/528

Gifreu, Josep (1988). Mass communications research in Catalunya. Barcelona: Servei de Publicacions de la Universitat Autònoma de Barcelona. ISBN: 9788474883534

Gomis, Lorenzo; Martínez-Albertos, José-Luis; Núñez-Ladevéze, Luis; Casasús, Josep-Maria (2002). “Encuesta: ¿ivive la comunicación periodística un cambio de paradigma?”. Anàlisi: quaderns de comunicació i cultura, v. 28, pp. 157-185. https://www.raco.cat/index.php/Analisi/article/view/15107/14948

Guillamet, Jaume (1996). Premsa, franquisme i autonomia: crònica catalana de mig segle llarg (1939-1995). Barcelona: Flor del Vent. ISBN: 9788489644014

Harnischmacher, Michael (2010). Journalistenausbildung im Umbruch: zwischen medienwandel und hochschulreform: Deustchland und USA im vergleich. Konstanz: UVK. ISBN: 9783867642668 
Holmgren, Rod (1968). "Europe's journalism education: vocational-type programs boom on the continent". Journalism educator, v. 23, n. 2, pp. 9-12.

https://doi.org/10.1177/107769586802300203

Hutchins, Robert M. (1938). “Is there a legitimate place for journalistic instruction? No!". The quill, v. 26, n. 3, pp. $12-20$. IAMCR (1970). Los profesores de periodismo. Pamplona: Ediciones Universidad de Navarra. ISBN: 9788431301378

Jones, Daniel E. (1989). “Aproximación a los estudios sobre economía de la Comunicación en España (1897-1988)”. Análisi: quaderns de comunicació i cultura, v. 12, pp. 135-153.

https://www.raco.cat/index.php/Analisi/article/view/41085

Jones, Daniel E. (1997). “Investigació sobre comunicació social a I'Espanya de les autonomies”. Análisi: quaderns de comunicació i cultura, v. 21, pp. 101-120.

https://www.raco.cat/index.php/Analisi/article/view/14958

Jones, Daniel E. (1998). “Investigación sobre comunicación en España: evolución y perspectivas”. Zer: revista de estudios de comunicación, v. 3, n. 5, pp. 13-51.

https://ojs.ehu.eus/index.php/Zer/article/view/17359/15144

Journalism Bulletin (1925), n. 4, p. 30.

Léauté, Jacques (1967). “¿Formación espontánea o enseñanza del periodismo?”. En: Benito, Ángel (ed.). Ciencia y enseñanza del periodismo. Pamplona: Ediciones Universidad de Navarra, pp. 121-136. ISBN: 9788431300012

López-Escobar, Esteban; Martín-Algarra, Manuel (2017). “Communication teaching and research in Spain: the calm and the storm". Publizistik, v. 62, pp. 83-105.

https://doi.org/10.1007/s11616-016-0306-4

López-Pan, Fernando (2010). “La periodística y sus partes. La propuesta de Josep Maria Casasús”. Sphera publica, n. 10, pp. 237-258.

https://www.redalyc.org/pdf/297/29719345016.pdf

Maheu, René (1948). “The work of Unesco in the field of mass communications”. Journalism quarterly, v. 25, n. 2, pp. $157-162$. https://doi.org/10.1177/107769904802500208

Martínez-Nicolás, Manuel (coord.) (2008). Para investigar la comunicación: propuestas teórico-metodológicas. Madrid: Tecnos. ISBN: 9788430948215

McLuhan, Marshall (1969). La galaxia Gutenberg: génesis del "homo typographicus". Madrid: Aguilar. ISBN: 9788403 140646

Mirando, Joseph A. (2002). "Training and education of journalists". In: Sloan, W. David; Parcell, Lisa M. American journalism: history, principles, practices. Jefferson, NC, USA: McFarland \& Company, pp. 76-86. ISBN: 0786413719

Montero-Díaz, Mercedes; Rodríguez-Salcedo, Natalia; Rodríguez-Virgili, Jordi; Del-Río, Jorge (2010). Historia de la publicidad y de las relaciones públicas en España. V. 2. La edad de oro de la comunicación comercial: desde 1960 hasta 2000. Sevilla: Comunicación Social. ISBN: 9788492860593

Morin, Edgar (1966). El espíritu del tiempo: ensayo sobre la cultura de masas. Madrid: Taurus. ISBN: 9788430610433

Mostaza, Bartolomé (1966). Periodismo, carrera de nivel docente superior. Gaceta de la prensa española, v. 19, n. 185, pp. 29-41.

Navas, Alejandro; Sánchez, José-Francisco (1995). "La formación de los profesionales de la comunicación". Situación, n. 4, pp. 279-294.

Nieto, Alfonso (2008). "Sobre los orígenes de las Facultades de Ciencias de la Información”. En: Gómez, B.; Hernández, S. (eds.). Estudios de periodística XIII. La periodística como disciplina universitaria: balance y perspectivas. Pamplona: Diario de Navarra, pp. 71-75. ISBN: 9788489103511

Nixon, Raymond B. (1958). "Journalism research around the world”. Journalism quarterly, v. 35, n. 1, pp. 3-146. https://doi.org/10.1177/107769905803500101

Palacio, Manuel (2001). Historia de la televisión en España. Barcelona: Gedisa. ISBN: 9788474328066

Peterson, Theodore (1960). "The changing role of journalism schools". Journalism quarterly, v. 37, n. 4, pp. $579-585$. https://doi.org/10.1177/107769906003700411

Plant, Robert (1967). La enseñanza práctica del periodismo en el Reino Unido. En: Benito, Ángel (ed.). Ciencia y enseñanza del periodismo. Pamplona: Ediciones Universidad de Navarra, pp. 139-150. ISBN: 9788431300012 
Recoder-Sellarés, María-José (2020). “De Ciencias de la Información a Ciencias de la Comunicación: cincuenta años de estudios de comunicación en la Universitat Autònoma de Barcelona". En: Ramírez-Alvarado, María-del-Mar; Clemente-Mediavilla, Jorge (coords.). Docencia \& investigación en comunicación en España. Observatorio ATIC, n. 3. Salamanca: Comunicación Social, pp. 21-33. ISBN: 9788417600297

Roglan, Joaquim (1992). El Grup Democràtic de Periodistes (1966-1976): crònica d'un periodisme esperançat. Barcelona: Col.legi de Periodistes de Catalunya. ISBN: 9788460429647

Salaverría, Ramón; Barrera, Carlos (2009). “The Spanish journalism education landscape”. In: Terzis, Georgios (ed.). European journalism education. Bristol, UK: Intellect Books, pp. 319-330. ISBN: 9781841502359

Sánchez-García, Pilar (2017). Periodistas (in)formados: un siglo de enseñanza periodística en España: historia y tendencias. Madrid: Universitas. ISBN: 9788479914783

Stephenson, Hugh; Mory, Pierre (1990). Journalism training in Europe. Brussels: Commission of the European Communities.

Sutton, Albert A. (1945). Education for journalism in the United States from its beginning to 1940. Evanston, IL, USA: Northwestern University Press.

Terrón-Montero, Javier (1981). La prensa en España durante el régimen de Franco: un intento de análisis político. Madrid: CIS. ISBN: 9788474760477

Vigil-Vázquez, Manuel (1987). El periodismo enseñado: de la Escuela de "El Debate" a Ciencias de la Información. Barcelona: Mitre. ISBN: 9788476520222

Weinberg, Steve (2008). A journalism of humanity: a candid history of the world's first journalism school. Columbia: University of Missouri Press. ISBN: 9780826217967

Williams, Sara-Lockwood (1929). Twenty years of journalism education: a history of the School of Journalism of the University of Columbia. Columbia: E.W. Stephens Publishing Company.

https://core.ac.uk/download/pdf/62792799.pdf

Williams, Walter (ed.) (1922). The Press Congress of the World in Hawaii. Columbia, Missouri: E.W. Stephens Publishing Company.

https://babel.hathitrust.org/cgi/pt?id=uc2.ark:/13960/t6nz8d71m\&view=1up\&seq=7

Williams, Walter (1925). "Are schools of journalism getting anywhere?”. The quill, v. 13, n. 1, pp. 7-9.

\section{Inforảrea}

\section{Ayudamos a tu organización en la transformación digital y el gobierno de la información}

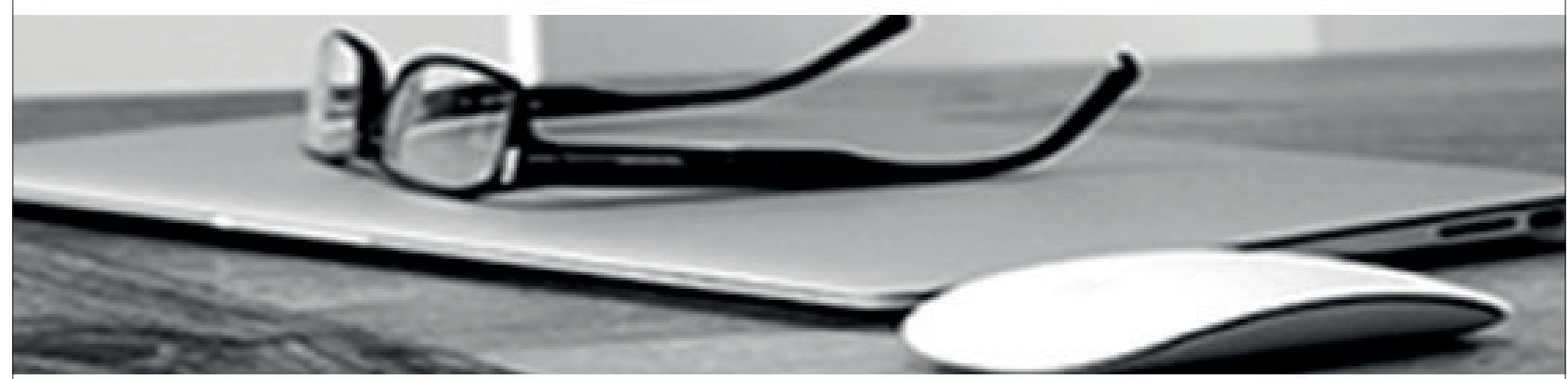

* Consultoría estratégica en gestión y gobierno de la información

* Gestión documental y "records management"

* Gestión de contenidos, intranets corporativas y entornos de colaboración

* Estudios especializados

Clientes satisfechos, cientos de empresas nacionales e internacionales y más de 30 años de experiencia son la mejor garantía de nuestra reputación. 